MILITARY TECHNIC, ,L COLLEGE CAIRO-EGYPT

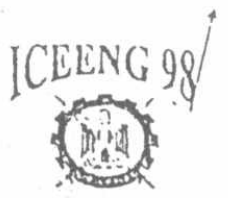

FIRST INTERNATIONAL CONF. ON

E: ECTRICAL ENGINEFRING

\title{
Techno-Economical Analysis of Wind-Turbine Generator/Utility Gride Aggregation
}

\author{
H.H.El-Tamaly* E.A.El-Sayed ${ }^{* *}$ and A.M.El-Tamaly***1 \\ Electrical Eng.Dept.,Faculty of Eng., Elminia University, \\ Elminia, Egypt
}

\begin{abstract}
This paper introduces a complete techno-analysis for wind turbine generator (WTG) system integrated with the utility grid (UG) from different side of views. The effects of maintenance duration, turbine type and selected site on the reliability as well as on the energy cost figure have been considered and investigated. A complete computer program has been designed and applied in the study to find out the most suitable site and the best turbine mode.

Finally, a complete comparative study between all used modes, dilferent selected sites has been carried out and then the most techno-economical and reliable one has been selected.
\end{abstract}

\section{Key Words}

Wind Turbine Generator, Wind Energy System, Utility Grid, Energy Cost Figure

\section{INTRODUCTION}

Threre is no doubt that the energy problem is the most one that take the attention overall the world. It has the priority over other problems in the developing countries [1]. The need to increase the electric energy sources, at the moment, is greater than before especially in the fields of food processing industry, new societies in the remote areas and lighting the village.

In Egypt, the government is going to increase the produced amount of the energy to cover the requirements of the new projects and societies that must be installed in the Egyptian deserts. Therefore a new sources of Egypt is required to cover the new requirments of energy. *Professor, Dept of Elect. Eng., **Assis. Prof., Dept. of Elcct. Eng., ***Assis. Lec., Dept. of Elect. Eng. Elminia
University, Elminia, EGYPT. 


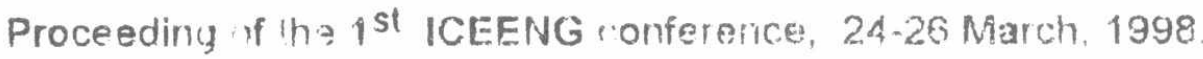

\section{DESIGN METHODOLOGY OF WIND ENERGY SYSTEM}

The design algorithm of the Wind Energy System (WES) has been identified according to the demand power represented by the suggested daily load curve and the wind speed of the site where the WES will be installed. The design procedure has been carried out for different sites in Egypt. These sites are Hurghada, Matruh and Sallum. The wind speed data have been collected for these sites for five years ago [5]. The selected sites have been choosen as a sample of the sites at which the wind speed satisfies the condition required for the wind turbine generator

The wind speed probability distribution (the probability that the wind speed lies in the intervals between cut-in and cut-out speeds) is important in wind energy studies. It may be used to evaluate the mean wind power, and to calculate the capacity factor calculation. The Wiebull probability distribution function for wind speed can be expressed as follows [3]:-

$\mathrm{F}(\mathrm{u})=(\mathrm{k} / \mathrm{c})(\mathrm{u} / \mathrm{c})^{\mathrm{k}-1} \operatorname{EXP}\left(-(\mathrm{u} / \mathrm{c})^{\mathrm{k}}\right)$

The Commulative probability can be expressed as:-

$\mathrm{P}\left(\mathrm{u}>\mathrm{u}_{\mathrm{a}}\right)=\operatorname{EXP}\left(-\left(\mathrm{u}_{\mathrm{a} / \mathrm{c}}\right)^{\mathrm{k}}\right)$

The distribution function can be obtained from Equation (1) as follows:-

$\mathrm{F}(\mathrm{u})=1-\operatorname{EXP}\left(-(\mathrm{u} / \mathrm{c})^{\mathrm{k}}\right)$

By the aid of least square method the above equations can be solved Taking the logarthm of (3) sides of Equation (3) it can be obtained as:

$\operatorname{Ln}\{-\operatorname{Ln}[1-\mathrm{f}(\mathrm{u})]\}=\mathrm{k} \operatorname{Ln} \mathrm{u}-\mathrm{k} \operatorname{Ln} \mathrm{c}$

This Equation can be put in the straight line form as follows:-

$\mathrm{Y}=\mathrm{aX}+\mathrm{b}$

where;

$\mathrm{Y}=\operatorname{Ln}\{-\operatorname{Ln}[1-\mathrm{f}(\mathrm{u})]\}, \quad \mathrm{a}=\mathrm{k}, \quad \mathrm{x}=\mathrm{Ln}(\mathrm{u})$ and $\mathrm{b}=-\mathrm{k} \operatorname{Ln}(\mathrm{c})$

By solving the Equation (4-b) for $\mathrm{k}$ and assuming that the number of different speeds available is denoted by $(w)$ we get:-

$k=\frac{\sum_{i=1}^{w}\left(x_{i}-x\right)\left(y_{i}-y\right) p^{2}\left(u_{i}\right)}{\sum_{i=1}^{w}\left(x_{i}-x\right)^{2} p^{2}\left(u_{i}\right)}$

$\mathrm{b}=\overline{\mathrm{Y}}-\overline{\mathrm{X}}=\frac{1}{w}\left(\sum_{i=1}^{w} \mathrm{Y}_{\mathrm{i}}\right)-\frac{\mathrm{a}}{\mathrm{w}}\left(\sum_{i=1}^{\infty} \mathrm{X}_{\mathrm{i}}\right)$

$\mathrm{c}=\operatorname{Exp}(-\mathrm{b} / \mathrm{k})$

The probability $\mathrm{P}\left(\mathrm{U}_{\mathrm{i}}\right)$ can be defined as follows:

$\mathrm{P}\left(\mathrm{U}_{\mathrm{i}}\right)=\mathrm{m}_{\mathrm{i}} / \mathrm{n}$

Also we can define the comulative distribution function $F(u)$ as the probability that a measured (9) speed will be less than or equal $\mathrm{U}_{\mathrm{i}}$ as [3].

$F(U)=\sum_{i=1}^{\infty} P\left(U_{i}\right)$

\section{APPLICATIONS OF WEIBULL METHOD FOR EGYPTIAN SITES:- Estimation of Weibull Parameters}

The applications have been made for the selected Egyptian sites. The data of these sites are detailed in the next sections. According to the previous analysis the computer program has been designed and 
applied. The data fed to the program is the wind speed $\left(\mathrm{U}_{\mathrm{i}}\right)$ collected over five years ago at national weather service stations and the corresponding ratio of this speeds over the year with respect to the total number of observation of the speeds ( 8760 in case of hourly observed speeds), the technical data of the used WTG types (see Table 1) and the demand load power (see Table 2). The result obtained is the capacity factor and number of required of WTG. Fig. 1. shows the flowchart of the used computer program. This program also, calculates the Weibull parameters for the different selected sites. This program estimates also the hourly generated power as well as the reliability of the WES and WES-UG according to the mathimatical model described in the next items.

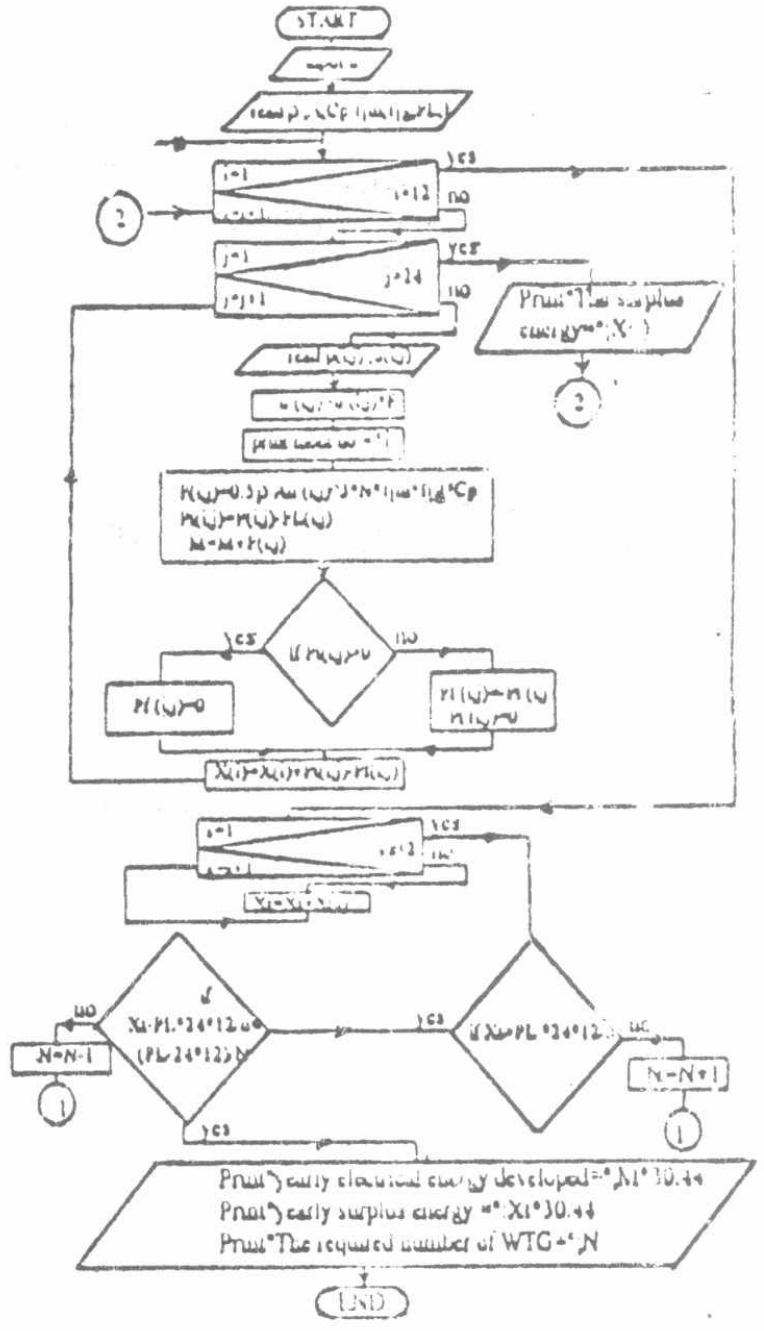

Fig. 1 Flowchart of the computer Program

The wind speed data has been modified to be at height of each type of wind-turbine generator above the ground level using the following Equation [4]:-

$$
\frac{U\left(z_{2}\right)}{U\left(z_{1}\right)}=\left(\frac{z_{2}}{z_{1}}\right)^{1 / 7}
$$

The application of that program for the different selected sites gives the Weibull parameters at each one. 


\section{Calculation of the Generated Power:}

The generated power can be estimated from the following formula [3]:-

$\mathrm{P}_{\mathrm{W}}=0.5 \rho \mathrm{AU}^{3}$

and $\rho$ can be estimated as follows:

$\rho=\frac{1.293\left(\mathrm{P}_{\mathrm{r}}-\mathrm{V}_{\mathrm{p}}\right)}{760} \cdot \frac{273}{\mathrm{~T}} \mathrm{~kg} / \mathrm{m}^{3}$

Assuming dry air $(\mathrm{Vp}=0)$, then

$\rho=\frac{1.293 \mathrm{P}_{\mathrm{r}}}{760} \cdot \frac{273}{\mathrm{~T}} \mathrm{~kg} / \mathrm{m}^{3}$

At standard conditions: $P_{r}=760 \mathrm{~mm}, \quad t=0.0^{\circ} \mathrm{C}, \quad T=273{ }^{\circ} \mathrm{k} \quad$ and $\rho=1.293 \mathrm{~kg} / \mathrm{m}^{3}$

The output electrical power generated from the wind energy system depends mainly on the wind speed, turbine angular velocity, efficiency of each element in the drive train and the type of used turbine. It can be expressed as follows [4]:-

$\mathrm{P}_{\mathrm{e}}=\mathrm{C}_{\mathrm{p}} \eta_{m} \eta_{\mathrm{G}}\left(0.5 \rho \mathrm{AU}^{3}\right)$

It is very important to determine the average power expected from a given turbine at a given site in order to determine the required number of turbines for each site. Thus, The average generated power can be defined as in Eqn (16). Table 3 indicates the average generated power and the required number of WTG.

$\mathrm{P}_{\mathrm{e}, \mathrm{ave}}=\int_{0}^{\infty} \mathrm{P}_{\mathrm{e}} \mathrm{F}(\mathrm{u}) \mathrm{du}$

By solving the above Equation the average generated power can be estimated From Equation.17), The quantity inside the practice is defined as the capacity factor $\left(\mathrm{C}_{f}\right)$ :

$P_{e, a v e}=\left[\frac{\operatorname{EXP}\left(-\left(U_{c} / C\right)^{k}\right)-\operatorname{EXP}\left(-\left(U_{r} / C\right)^{k}\right)}{\left(U_{r} / C\right)^{k}-\left(U_{c} / C\right)^{k}}-\operatorname{EXP}\left(-\left(U_{f} / C\right)^{k}\right)\right] \cdot P_{e R}$

The capacity factor has been calculated and drawn as shown in Fig.2.

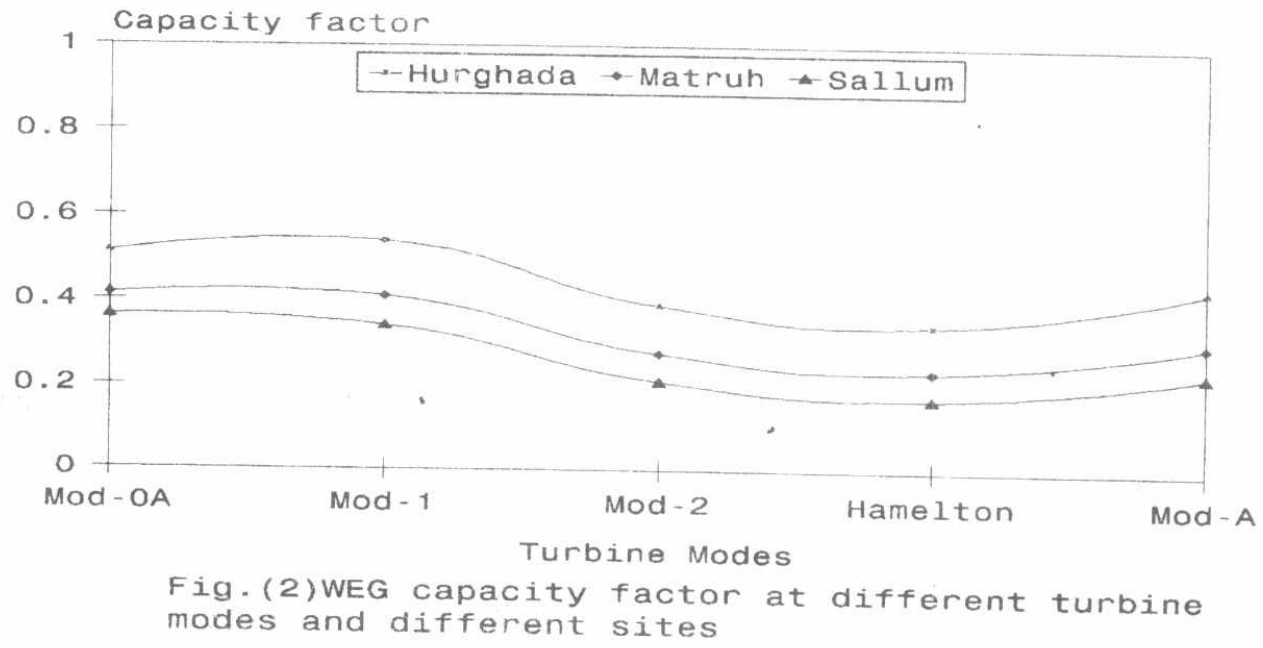


Proceedino if the $1^{\text {st }}$ ICEENG confelence, 24-26 March, 1998.

Table 1: Reference Data of different turbine modes [4]

\begin{tabular}{|l|l|l|l|l|l|}
\hline \multicolumn{1}{|c|}{ Type } & Mod-OA & Mod-1 & Mod-2 & Hamilton & Mod-A \\
\hline $\begin{array}{c}\text { Item } \\
\text { Rotor diameter, m } \\
\text { (ft) }\end{array}$ & $\begin{array}{l}38.1 \\
(125)\end{array}$ & $\begin{array}{l}84 \\
(275)\end{array}$ & $\begin{array}{l}91.5 \\
(300.2)\end{array}$ & $\begin{array}{l}77.6 \\
(255)\end{array}$ & $\begin{array}{l}40 \\
(131.2)\end{array}$ \\
\hline $\begin{array}{c}\text { Rotor Ground Clearance,m } \\
\text { (ft) }\end{array}$ & 9.3 & $\begin{array}{l}15 \\
(50)\end{array}$ & $\begin{array}{l}14.25 \\
(46.8)\end{array}$ & $\begin{array}{l}41.2 \\
(135)\end{array}$ & $\begin{array}{l}25 \\
(82)\end{array}$ \\
\hline Rotor speed, r.p.m & & 21.6 & & & \\
\hline Rated wind speed, m/sec & 9.96 & 10 & 12.4 & 14.2 & 13 \\
\hline Cut-in wind speed, m/sec & 4.22 & 4.96 & 6.3 & 6 & 5 \\
\hline Cut-out wind speed, m/sec & 17.78 & 21.87 & 20.1 & 21 & 25 \\
\hline Gear box efficiency & 0.85 & 0.86 & 0.85 & 0.86 & 0.86 \\
\hline Synch. generator efficiency & 0.94 & 0.95 & 0.96 & 0.96 & 0.95 \\
\hline Power, kW & 200 & 1500 & 2500 & 3000 & 500 \\
\hline
\end{tabular}

Table 2. Load specification

\begin{tabular}{|l|l|l|}
\hline $\begin{array}{l}\text { Maximum Load } \\
\text { Demand (kW) }\end{array}$ & $\begin{array}{l}\text { Maximum Load } \\
\text { Duration (Hrs) }\end{array}$ & $\begin{array}{l}\text { Load } \\
\text { Factor }\end{array}$ \\
\hline 100 & 2 & 0.8 \\
\hline
\end{tabular}

Table 3: Generated Power and corresponding required number of turbine

\begin{tabular}{|l|l|l|l|l|}
\hline Type & Sites & $\mathrm{CF}$ & Pe,av,kW & No. of WTG \\
\hline \multirow{2}{*}{$\begin{array}{l}\text { Mod-OA } \\
200 \mathrm{~kW}\end{array}$} & Hurghada & 0.5119119 & 102.38238 & 405 \\
\cline { 2 - 5 } & Matruh & 0.4145566 & 82.91132 & 500 \\
\cline { 2 - 5 } & Sallum & 0.3639845 & 72.7969 & 569 \\
\hline \multirow{3}{*}{$\begin{array}{l}\text { Mod-1 } \\
\text { 1500 kW }\end{array}$} & Hurghada & 0.5391415 & 808.71225 & 52 \\
\cline { 2 - 5 } & Matruh & 0.410344 & 615.516 & 68 \\
\cline { 2 - 5 } & Sallum & 0.3409325 & 511.39875 & 81 \\
\hline \multirow{3}{*}{$\begin{array}{l}\text { Mod-2 } \\
\text { 2.51 MW }\end{array}$} & Hurghada & 0.39008 & 975.2 & 43 \\
\cline { 2 - 5 } & Matruh & 0.276 & 690 & 60 \\
\cline { 2 - 5 } & Sallum & 0.21 & 525 & 79 \\
\hline \multirow{3}{*}{ Hamilton } & Murghada & 0.3454821 & 1036.4463 & 40 \\
\cline { 2 - 5 } & Matruh & 0.2363106 & 708.9318 & 59 \\
\cline { 2 - 5 } & Sallum & 0.1729523 & 518.8569 & 80 \\
\hline \multirow{3}{*}{$\begin{array}{l}\text { Mod-A } \\
500 \mathrm{~kW}\end{array}$} & Hurghada & 0.4334011 & 216.70055 & 191 \\
\cline { 2 - 5 } & Matruh & 0.3039119 & 151.95595 & 273 \\
\cline { 2 - 5 } & Sallum & 0.2322154 & 161.1077 & 257 \\
\hline
\end{tabular}

\section{SYSTEM P.ELIABILITY ESTIMATION}

The calculation of the WES reliability depends mainly on reliability of each item in the system such as generator;, transformer, circuit breaker, rotor aero dynamic, ....etc. The reliability can be calculated by mult' plying all values of reliability of all elements of the whole system. Fig. 3 shows the integration betwee $n$ the WES and UG and the required elements necessary for the interconnection. The most effective factors on the reliability of WES are the wind speed which depends on the site where the syst: $\mathrm{m}$ has been built, according to the following Equation [6]:- 
Proceeding if the $1^{\text {st }}$ ICEENG conierence, $24-26$ March, 1998.

EP. 7296

$R_{w}=\operatorname{EXP}\left[-\left(\frac{U_{c}}{C}\right)^{k}\right]$

On the other hand the reliability of the W.T.C. depends on the site where the plant has been built and on the type of used turbine. The reliability of W.T.G can be calculater's according to the following Equation:-

$\mathrm{R}_{\mathrm{WTG}}=\mathrm{R}_{\mathrm{W}} \cdot \mathrm{R}_{\mathrm{A}} \cdot \mathrm{R}_{\mathrm{B}} \cdot \mathrm{R}_{\mathrm{C}} \cdot \mathrm{R}_{\mathrm{D}} \cdot \mathrm{R}_{\mathrm{E}} \cdot \mathrm{R}_{\mathrm{F}} \cdot \mathrm{R}_{\mathrm{G}} \cdot \mathrm{R}_{\mathrm{H}}$

Whereas the reliability of the utility grid is independent on the site and it can be estimated as [7]:-

$\mathrm{RUG}=\mathrm{R}_{1} \cdot \mathrm{R}_{2}$ where; $\mathrm{R}_{1}$ and $\mathrm{R}_{2}$ can be defined as follows:

$\mathrm{R}_{1}=\mathrm{R}_{\mathrm{G}} \cdot \mathrm{R}_{\mathrm{X}} \cdot \mathrm{R}_{\mathrm{S}} \cdot \mathrm{R}_{\mathrm{T}} \cdot \mathrm{R}_{\mathrm{U}} \quad \& \quad \mathrm{R}_{2}=\mathrm{R}_{\mathrm{J}} \cdot \mathrm{R}_{\mathrm{K}} \cdot \mathrm{R}_{\mathrm{L}} \cdot \mathrm{R}_{\mathrm{M}} \cdot \mathrm{R}_{\mathrm{N}} \cdot \mathrm{R}_{\mathrm{O}} \cdot \mathrm{R}_{\mathrm{P}}$

The reliability of each element has been determined as follows:

$\mathrm{R}=\operatorname{EXP}(-\lambda \mathrm{t})$

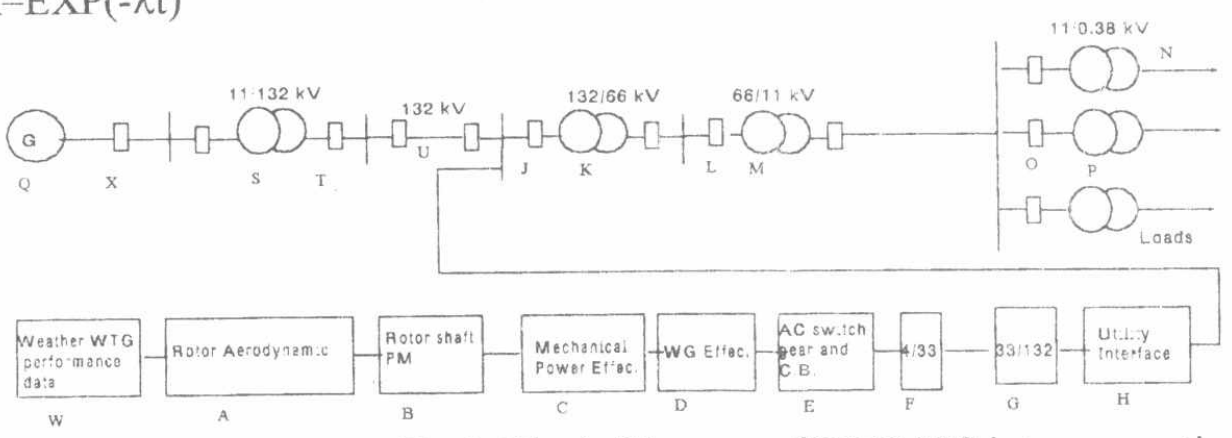

Fig. 3. Block Diagram of WES-UG interconnecting

The reliability of the aggregation between the UG and WES is given by:-

$\mathrm{R}_{\text {ug-wtg }}=\left[1-\left(1-\mathrm{R}_{1}\right)\left(1-\mathrm{R}_{\text {wtg }}\right)\right] \mathrm{R}_{2}$

\section{RESULTS AND DISCUSSION}

Fig. 5 shows the relation between the turbine type used in the study versus the energy cost figure . (ECF) at different selected sites. The energy cost figure for Mod-0 is the best one comparing with the other types as seen from the Figure. It varies between $0.06 \$$ at Hurghada site and $0.14 \$$ at Salum site where as the highest energy cost figure is at Matruh site when the Hamilton turbine type is used and it is found $0.42 \$$. Tables 4,5 and 6 clear the effect of maintenance period on the system reliability at minimum failure rate at Hurghada site. The system reliability decreases as the maintenance period increases. The combination UG-WTG has higher reliability than when the UG or WTG is operating alone. The system reliability rapidly decreases at minimum failure rate in the case of using WTG alone at Hurghada site.

Tables 7,8 and 9 show the system reliability against maintenance period at minimum, average and maximum failure rate respectively at Matruh site. Comparing these Tables with Tables 4, 5 and 6, it can be seen that the reliability at Matruh site is lower than that at Hurghada site with about $10 \%$ in case of operating WTG alone but, they are approximately the same in the two other cases (UG and UG-WTG). The system reliability is become lower at Matruh site than that at Salum-site, Tables 10,11 and 12, in case of use WTG alone. From this comparison, it can be concluded that the highest system reliability is given at Hurghada site at different investigated turbine types. 
Proce ading if the $1^{\text {st }}$ ICEENG conference, 24-26 March, 1998.

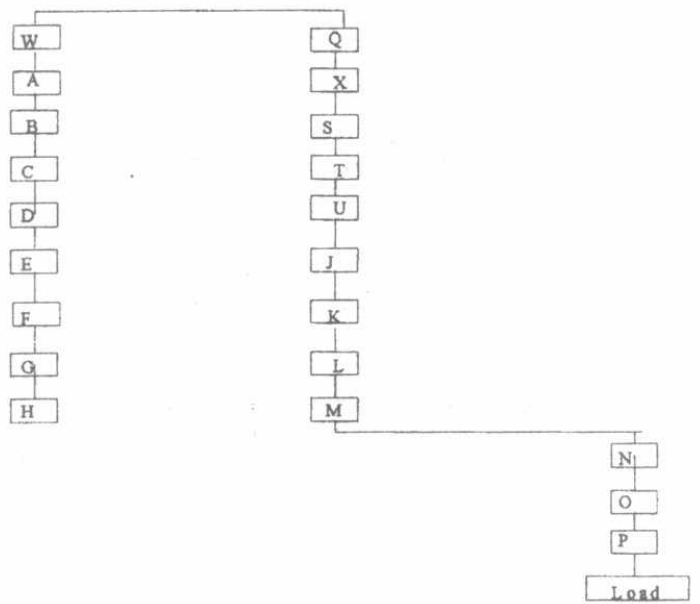

Fig(4) Block diagram for the aggregation between UG and WTG

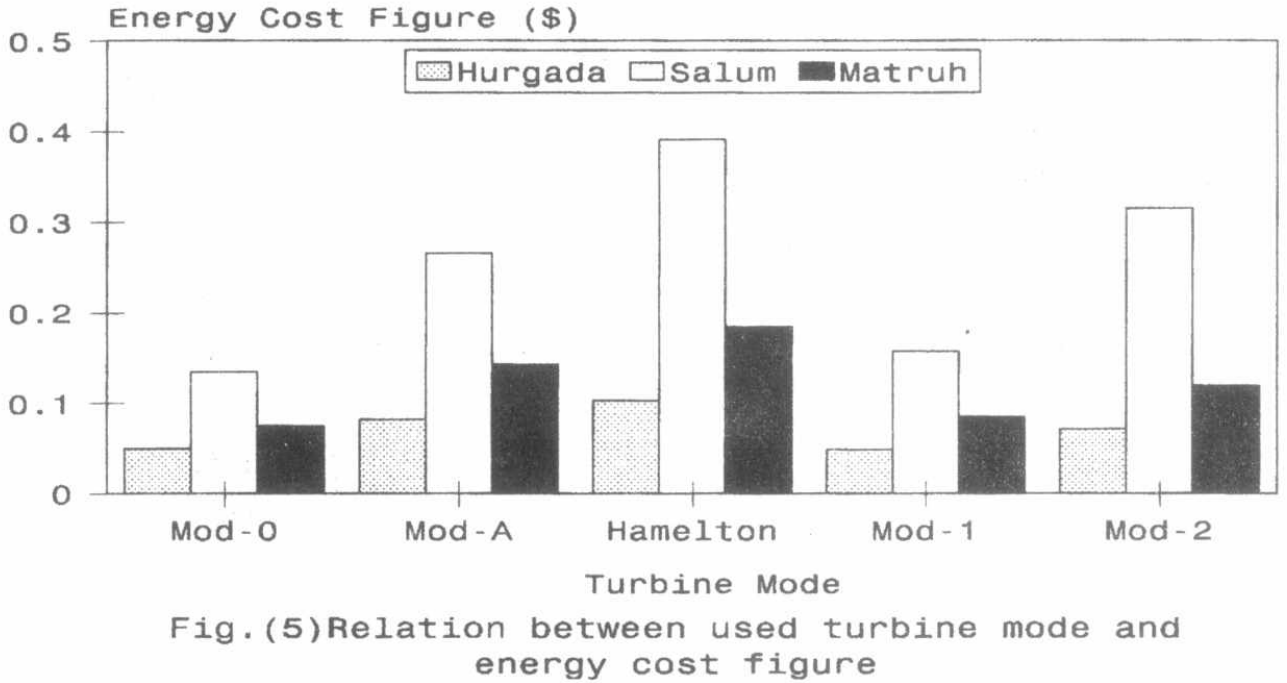

Table 4: Effect of maintenance period on the system reliability at Hurghada site (min.failure r.)

\begin{tabular}{|l|l|l|l|l|l|}
\hline $\begin{array}{c}\text { maintenance } \\
\text { period (day) } \\
\text { case }\end{array}$ & 15 & 30 & 90 & 180 & 360 \\
\hline UG & 0.9998765 & 0.9982614 & 0.9947935 & 0.9896141 & 0.979336 \\
\hline WTG & 0.8198014 & 0.8175226 & 0.808624 & 0.795458 & 0.769765 \\
\hline WTG-UG & 0.9999162 & 0.9999560 & 0.9986397 & 0.9971599 & 0.973174 \\
\hline
\end{tabular}

Table 5: Effect of maintenance period on the system reliability at Hurghada site (ave. failure r.)

\begin{tabular}{|l|l|l|l|l|l|}
\hline $\begin{array}{c}\text { maintenance } \\
\text { period (day) } \\
\text { case }\end{array}$ & 15 & 30 & 90 & 180 & 360 \\
\hline UG & 0.9981855 & 0.9947634 & 0.9891688 & 0.9784551 & 0.957376 \\
\hline WTG & 0.8163527 & 0.8102923 & 0.7886361 & 0.7566191 & 0.6964317 \\
\hline WTG-UG & 0.9995075 & 0.997816 & 0.9967883 & 0.9929877 & 0.9838086 \\
\hline
\end{tabular}


Proce odiny if the $1^{\text {st }}$ ICEENG conference, 24-26 March, 1998.

EP. 7298

Table 6: Effect of maintenance period on the system reliability at Hurghada site (max. failure .r)

\begin{tabular}{|l|l|l|l|l|l|}
\hline $\begin{array}{c}\text { maintenance } \\
\text { period (day) } \\
\text { case }\end{array}$ & 15 & 30 & 90 & 180 & 360 \\
\hline UG & 0.9958042 & 0.991634 & 0.9748274 & 0.9508488 & 0.895976 \\
\hline WTG & 0.8097831 & 0.795777 & 0.745802 & 0.6766607 & 0.555003 \\
\hline WTG-UG & 0.9985912 & 0.997098 & 0.9901067 & 0.9780448 & 0.940458 \\
\hline
\end{tabular}

Table7: Effect of maintenance period on the system reliability at Matruh site (min.failure r.)

\begin{tabular}{|l|l|l|l|l|l|}
\hline $\begin{array}{l}\text { maintenance } \\
\text { period (day) } \\
\text { case }\end{array}$ & 15 & 30 & 90 & 180 & 360 \\
\hline UG & 0.9998765 & 0.9982614 & 0.9947935 & 0.9896141 & 0.979336 \\
\hline WTG & 0.7124112 & 0.7104309 & 0.702698 & 0.6912566 & 0.668929 \\
\hline WTG-UG & 0.999911 & 0.99939 & 0.9981359 & 0.9961714 & 0.962212 \\
\hline
\end{tabular}

Table 8: Effect of maintenance period on the system reliability at Matruh site (min. failure r.)

\begin{tabular}{|l|l|l|l|l|l|}
\hline $\begin{array}{l}\text { maintenance } \\
\text { period (day) } \\
\text { case }\end{array}$ & 15 & 30 & 90 & 180 & 360 \\
\hline UG & 0.9981855 & 0.9947634 & 0.9891688 & 0.9784551 & 0.957376 \\
\hline WTG & 0.7094142 & 0.7041477 & 0.6853284 & 0.6575055 & 0.605202 \\
\hline WTG-UG & 0.9993343 & 0.9988837 & 0.9957902 & 0.991084 & 0.980346 \\
\hline
\end{tabular}

Table 9: Effect of maintenance period on the system reliability at Matruh site (min.failure r.)

\begin{tabular}{|l|l|l|l|l|l|}
\hline $\begin{array}{c}\text { maintenance } \\
\text { period (day) } \\
\text { case }\end{array}$ & 15 & 30 & 90 & 180 & 360 \\
\hline UG & 0.9958042 & 0.991634 & 0.9748274 & 0.9508488 & 0.895976 \\
\hline WTG & 0.7028362 & 0.6915345 & 0.648105 & 0.5880212 & 0.482300 \\
\hline WTG-UG & 0.9982261 & 0.9963829 & 0.988105 & 0.9744822 & 0.93498 \\
\hline
\end{tabular}

Table 10: Effect of maintenance period on the system reliability at Sallum site (min.failure r.)

\begin{tabular}{|l|l|l|l|l|l|}
\hline $\begin{array}{c}\text { Maintenance } \\
\text { period (day) } \\
\text { case }\end{array}$ & 15 & 30 & 90 & 180 & 360 \\
\hline UG & 0.9998765 & 0.9982614 & 0.9947935 & 0.9896141 & 0.979336 \\
\hline WTG & 0.682866 & 0.6809678 & 0.6735556 & 0.6625887 & 0.641187 \\
\hline WTG-UG & 0.9999096 & 0.9993432 & 0.9979972 & 0.9958995 & 0.9591971 \\
\hline
\end{tabular}

Table 11: Effect of maintenance period on the system reliability at Sallum site (m.failure r.)

\begin{tabular}{|l|l|l|l|l|l|}
\hline $\begin{array}{c}\text { Maintenance } \\
\text { period (day) } \\
\text { case }\end{array}$ & 15 & 30 & 90 & 180 & 360 \\
\hline UG & 0.9981855 & 0.9947634 & 0.9891688 & 0.9784551 & 0.957376 \\
\hline WTG & 0.6799933 & 0.6749452 & 0.6569064 & 0.6302374 & 0.580103 \\
\hline WTG-UG & 0.9992867 & 0.9973061 & 0.9955156 & 0.9905602 & 0.979393 \\
\hline
\end{tabular}


Proneediry of the 1 st ICEEN(s conference, 24-26 Miarch, 1998. EP-7_299

Table 12: Effect of maintenance period on the system reliability at Sallum site (m.failure r)

\begin{tabular}{|l|l|l|l|l|l|}
\hline $\begin{array}{l}\text { Maintenance } \\
\text { period (day) } \\
\text { case }\end{array}$ & 15 & 30 & 90 & 180 & 360 \\
\hline UG & 0.9958042 & 0.991634 & 0.9748274 & 0.9508488 & 0.8959764 \\
\hline WTG & 0.6736881 & 0.6628551 & 0.621227 & 0.5636347 & 0.4622982 \\
\hline WTG-UG & 0.9981257 & 0.996186 & 0.9875545 & 0.9735021 & 0.9333629 \\
\hline
\end{tabular}

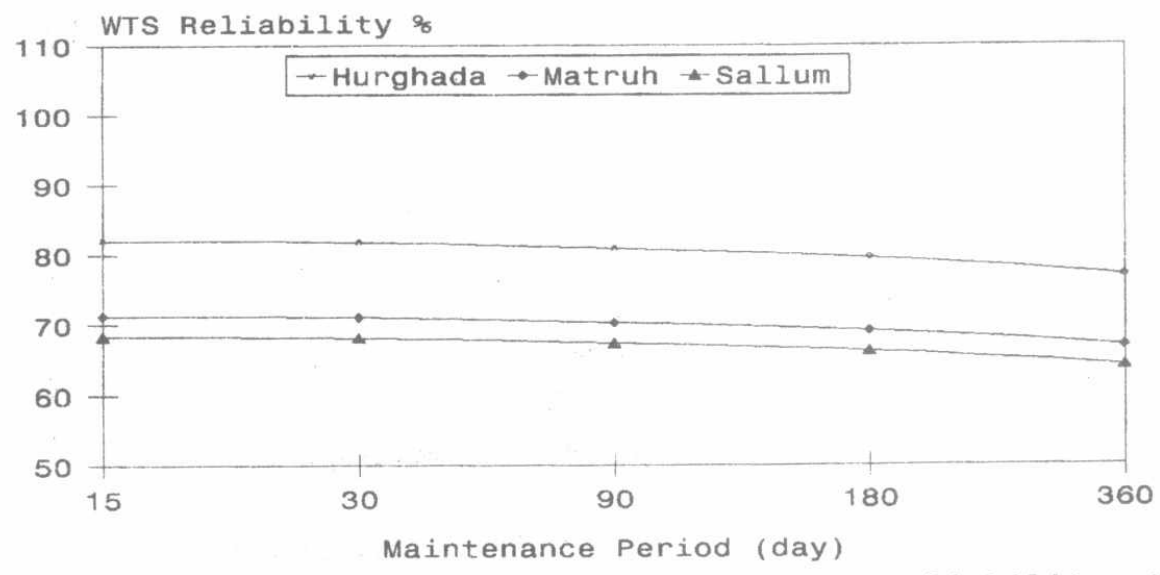

Fig.(6)Comparison between the WTG reliability at different sites(at minimum failure rate)

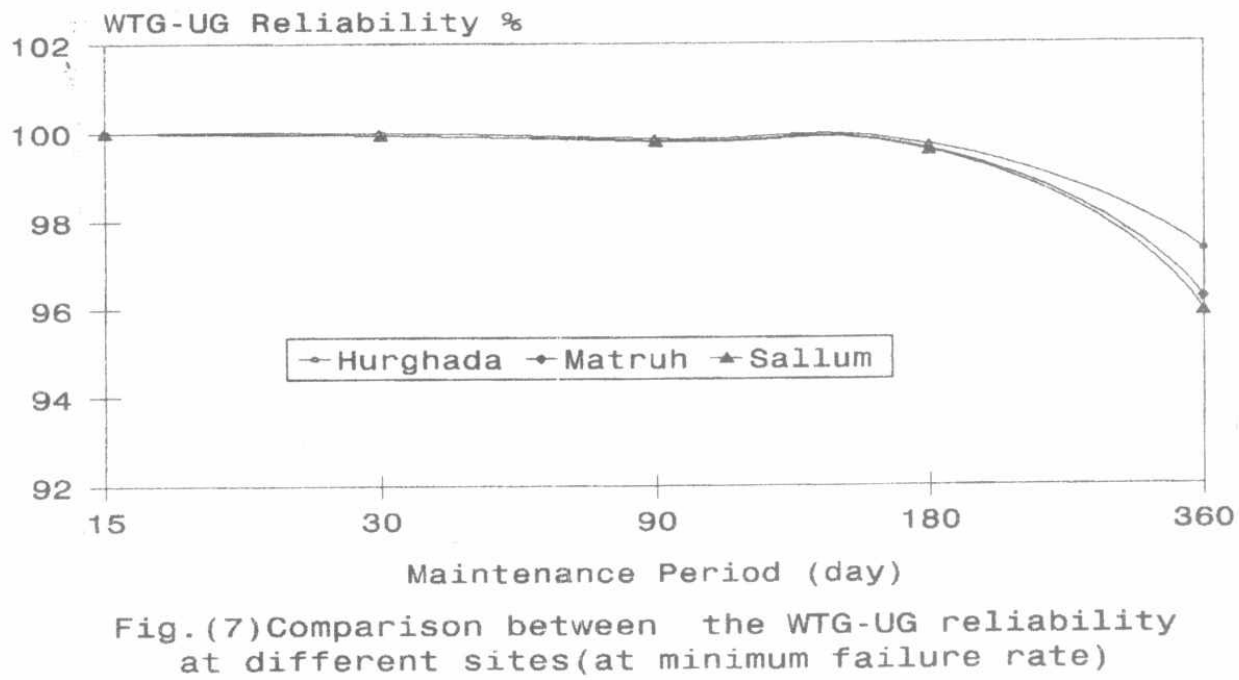

\section{CONCLUSION}

The wind energy system has been designed and applied to supply a certain load and to be integrated with the UG. The UG issued lake as an infinite storage. Five modes of WTG have been selected and used in the design of WES. These modes are Mod1, Mod 2, Mod OA, Mod A and Hamilton Mod. The application of the designed WES has been carried out at three different Egyptian sites. These sites are Hurghada, Matruh and Sallum.

The reliability of WES-UG aggregation has been investigated and computed under different conditions of maintenance period at each selected site. The required number of WTG at each site has been determined and the optimum (lowest) number has been found out. An economical study has 
Proceeding of the $1^{\text {st }}$ ICEENG confererice, 24-26 March, 1998.

been applied on different studied cases and it is found that the WES which used Mod OA has the lower energy cost figure(ECF) at all sites and the ECF of WES that designed to be installed at Hurghada site has the lowest value.

\section{REFERENCES}

[1] Ali Kettani, M., "Direct Energy Conversion", Book, Eddision Wesley Publishing Company Reading, Massachustts Menlo Park, California London. Don Mills, Ontario.

[2] Gary L. Johnson, "Wind Energy System", Book, Prentic-Hall, iNC, England Cliffs N.J 0.07623 , VSA, 1985.

[3] Gerald W. Koepple, "Putnams Power From The Wind", Book, VAN Nostrand Reinnold Company.

[4] "The Available Wind Data In Egypt", Report Prepared by A.Mobark under the contract of "Development of Wind-Solar Power Generation System for Rural Areas in Egypt", with Ministry of Electricity and Energy of Egypt, 1982.

[5] Macomber, H.L. et al, "Photovoltiac stand-alone Power System Preliminary Engineering Design", Hand Book, Prepared for NASA, Contract DEN3-195, August 1981.

[6] Ramakumar, "Renewable Energy Sources and Developing Countries", IEEE, Vol.PAS-102, No.2, Feb., 1983.

[7] El-Tamaly, H.H. et al, "Reliability of PVPS-UG Aggregation Estimation and Analysis", Printed from the Mansoura Engineering Journal, Vol.13, No.1, June 1987, pp.E13-E24.

\section{NOMENCKLATURE}

$\mathrm{k} \quad$ is the shape factor

c is the scale factor

$\overline{\mathrm{X}}$ and $\overline{\mathrm{Y}}$ are the average of $\mathrm{X}_{\mathrm{i}}$ and $\mathrm{Y}_{\mathrm{i}}$ respectively

$\mathrm{m}_{\mathrm{i}} \quad$ is the number of observations of a specific wind speed $\left(\mathrm{U}_{\mathrm{i}}\right)$

$\mathrm{n} \quad$ is the total number of observed speeds

$\mathrm{U}$ is the wind speed in $\mathrm{m} / \mathrm{s}$

A is the exposed area in $\mathrm{m}^{2}$

$\rho \quad$ is the density of air in $\mathrm{kg} / \mathrm{m}^{3}$ and a function of pressure and relative humidity and it is

$\mathrm{P}_{\mathrm{r}} \quad$ is the pressure in mm of mercury

$\mathrm{T}$ is the temperature in $\mathrm{O}_{\mathrm{k}}$

$\mathrm{Vp}$ is the pressure of water vapor assuming $\operatorname{dry} \operatorname{air}(\mathrm{Vp}=0)$

$\eta_{\mathrm{m}} \quad$ is the mechanical efficiency

$\eta_{\mathrm{G}}$ is the generation efficiency respectively,

$\mathrm{C}_{\mathrm{p}}$ is the coefficient of performance.

$\mathrm{F}(\mathrm{u})$ is the Weibull function

$\mathrm{R}_{\mathrm{A}}$ is reliability of rotor aero dynamic

$R_{B}$ is reliability of rotor shaft

$\mathrm{R}_{\mathrm{C}}$ is reliability of mechanical power

$R_{D} \quad$ is reliability of wind generator

$\mathrm{R}_{\mathrm{H}}$ is reliability of Utility interface

$R_{W} \quad$ is reliability of wind speed

$R_{G}$ is reliability of generator

$\mathrm{R}_{\mathrm{X}}, \mathrm{R}_{\mathrm{T}}, \mathrm{R}_{\mathrm{J}}, \mathrm{R}_{\mathrm{O}}, \mathrm{R}_{\mathrm{L}}, \mathrm{R}_{\mathrm{P}}$ are reliability of circuit breakers

$R_{U}$ is reliability of transmission line

$\mathrm{R}_{\mathrm{S}}, \mathrm{R}_{\mathrm{K}}, \mathrm{R}_{\mathrm{M}}$ are reliability of transformer 1,2 and 3 respectively 
Proceeding of the $1^{\text {st }}$ ICEI:NG conference, 24-26 March, 1998.

$\mathrm{R}_{\mathrm{N}} \quad$ is reliability of feeders

$\lambda$ is the failure rate (f.r.),

$t \quad$ is the maintenance period per day.

$\mathrm{R}_{\mathrm{E}}, \mathrm{R}_{\mathrm{F}}, \mathrm{R}_{\mathrm{G}}$ are reliability of transformer 5,6 and 7 respectively 
